\title{
PENGARUH LUAS LAHAN DAN PERMINTAAN TERHADAP PRODUKSI KAKAO DI SUMATERA UTARA TAHUN 2007-2012
}

\author{
Jerry Arlis Harahap \\ Alumni Jurusan Manajemen Fakultas Ekonomi Universitas Negeri Medan \\ Edison Sagala \\ Dosen Jurusan Manajemen Fakultas Ekonomi Universitas Negeri Medan
}

\begin{abstract}
Abstrak
Tujuan dari penelitian ini adalah untuk mengetahui dan menganalisis mengenai pengaruh luas lahan dan permintaan terhadap produksi kakao di Sumatera Utara. Sumber data dari penelitian ini adalah data sekunder untuk periode 2007-2012 yang diperoleh dari BPS. Data yang digunakan adalah data luas lahan, permintaan dan produksi kakao. Tekhnik analisis data yang digunakan adalah regresi linear berganda dengan model : $Y=a+b_{1} X_{1}+b_{2} X_{2}$. Dari hasil analisis data maka diperoleh hasil regresi linear berganda : $Y=-4397,631+0,820 X_{I^{-}} 0,046 X_{2}$. Hasil menunjukkan bahwa secara simultan luas lahan dan permintaan mempunyai pengaruh yang signifikan terhadap produksi kakao di Sumatera Utara, yang terlihat dari nilai $F_{\text {hitung }}=10,895$ lebih besar dari $F_{\text {tabel }}=9,55$ dan nilai signifikansi 0,026 berada dibawah 0,05 $(0,026<0,05)$. Hasil analisis secara parsial menunjukkan bahwa luas lahan $\left(X_{I}\right)$ berpengaruh positif dan signifikan terhadap produksi (Y) yang terlihat dari nilai $t_{\text {hitung }}=2,874$ lebih besar dari $t_{\text {tabel }}=2,776$ dan nilai signifikansi sebesar 0,015 berada dibawah 0,05 $(0,010<0,05)$. Sedangkan permintaan $\left(X_{2}\right)$ tidak mempunyai pengaruh yang signifikan terhadap produksi (Y) yang terlihat dari nilai $t_{\text {hitung }}=-0,311$ lebih kecil dari $t_{\text {tabel }}=2,776$ dan nilai signifikansi 0,776 berada diatas 0,05 (0,776>0,05). Selanjutnya diperoleh nilai koefisien determinasi sebesar $76,5 \%$ yang berarti luas lahan $\left(X_{1}\right)$ dan permintaan $\left(X_{2}\right)$ mempunyai kontribusi terhadap produksi $(Y)$ dan selebihnya $23,5 \%$ dipengaruhi faktor lain. Berdasarkan hasil analisis tersebut maka dapat ditarik kesimpulan bahwa luas lahan dan permintaan secara bersama-sama berpengaruh terhadap produksi kakao di Sumatera Utara. Secara parsial, luas lahan kakao berpengaruh signifikan terhadap produksi kakao di Sumatera Utara sedangkan permintaan tidak berpengaruh signifikan terhadap produksi kakao di Sumatera Utara.
\end{abstract}

Kata kunci: Luas Lahan, Permintaan, dan Produksi

\section{PENDAHULUAN}

Subsektor

perkebunan merupakan salah satu sektor pertanian yang dapat meningkatkan kesejahteraan rakyat dalam pembangunan perekonomian Indonesia. Pada saat ini, subsektor perkebunan dapat menjadi penggerak pembangunan nasional karena adanya dukungan sumber daya yang besar berorientasi pada ekspor, komponen impor yang kecil dan menghasilkan devisa non migas dalam jumlah yang besar. Kakao merupakan salah satu komoditas unggulan sub sektor perkebunan dari 20 komoditas yang dicanangkan untuk dikembangkan secara besar-besaran di Indonesia.

Melalui komoditas ini, Indonesia berhasil menjadi produsen kedua terbesar di dunia setelah Pantai Gading, walaupun pada tahun 2003 tergeser keurutan ketiga oleh Ghana karena mengganasnya serangan hama 
penggerek buah kakao (Badan Litbang Pertanian, 2005).

Beberapa tahun belakangan ini produksi kakao di Indonesia bersifat fluktuatif. Hal ini disebabkan oleh rendahnya mutu kakao yang umumnya dihasilkan oleh perkebunan rakyat. Untuk itu perlu perbaikan di bidang produksi berupa masa prapanen maupun pasca panen, perlu lebih ditingkatkan penyuluhan dan bimbingan kepada para petani produsen dalam menggunakan bibit, perawatan tanaman, melakukan panen dalam waktu yang tepat serta pengolahan hasil yang lebih baik sehingga menghasilkan kakao yang bermutu tinggi.

Oleh karena itu peningkatan peranan sektor pertanian sebagai salah satu alternatif sumber penghasilan bagi petani merupakan pilihan yang masih relevan dan sangat mendesak untuk diperbaharui, karena produktivitas hasil pertanian beberapa tahun terakhir mengalami penurunan.
Salah satu penyebabnya adalah tidak efisiennya usaha intensifikasi pertanian seperti kurangnya perawatan lahan dan frekuensi pemupukan yang menurun. Penurunan frekuensi pemupukan ini disebabkan ketidakmampuan petani untuk membeli pupuk akibat harga yang tinggi. Untuk itu dukungan Departemen Pertanian untuk melaksanakan program intensifikasi, sangat dibutuhkan dengan memberikan regulasi yang mendukung petani misalnya dengan pengendalian harga pupuk dan pemberian penyuluhan.

$$
\text { Sebenarnya tanpa }
$$

pemeliharaan yang intensif pun produksi kakao yang dihasilkan cukup lumayan untuk menambah penghasilan. Tetapi bila pemeliharaan dan pengolahan cukup baik, maka usaha pertanian ini akan mendatangkan keuntungan yang berlipat ganda.

Tabel 1. Daerah Penghasil Kakao Indonesia Tahun 2013

\begin{tabular}{|c|c|}
\hline Provinsi & Jumlah Produksi (Ton) \\
\hline Sulawesi Selatan & 204746 \\
\hline Sulawesi Tengah & 157065 \\
\hline Sulawesi Tenggara & 131687 \\
\hline Sumatera Utara & 65568 \\
\hline Kalimantan Timur & 35654 \\
\hline Lampung & 31545 \\
\hline Daerah Lainnya & 122956 \\
\hline
\end{tabular}

Sumber : Biro Pusat Statistik

Dari tabel 1. tersebut menunjukkan daerah penghasil komoditi tanaman jenis kakao. "Sumatera Utara menjadi salah satu dari 7 daerah penghasil kakao terbanyak di Indonesia sebanyak 65.568 ton" (BPS 2013).
Ada 6 daerah yang menjadi wilayah potensi pengembangan komoditi kakao di Sumatera Utara yaitu : Kabupaten Nias Utara, Kabupaten Deli Serdang, Kabupaten Simalungun, Kabupaten Mandailing Natal, Kabupaten Tapanuli Selatan, Kabupaten Nias Selatan. 
JURNAL PLANS

Penelitian Ilmu Manajemen \& Bisnis

ISSN: 1978-7057

Tabel 2. Data Jumlah Produksi Kakao Sumatera Utara tahun 2007-2013

\begin{tabular}{|c|c|}
\hline TAHUN & JUMLAH PRODUKSI (TON) \\
\hline 2007 & $\mathbf{6 0 . 2 0 2}$ \\
\hline 2008 & $\mathbf{6 0 . 2 5 3}$ \\
\hline 2009 & $\mathbf{6 5 . 0 5 2}$ \\
\hline 2010 & 66.466 \\
\hline 2011 & $\mathbf{5 6 . 1 8 3}$ \\
\hline 2012 & $\mathbf{5 7 . 5 6 7}$ \\
\hline 2013 & $\mathbf{6 5 . 5 6 8}$ \\
\hline
\end{tabular}

\section{Sumber : BPS Sumatera Utara}

Berdasarkan tabel 2. diatas produksi kakao Sumatera Utara terus bersifat fluktuatif dari tahun 20072013 dimana pada tahun 2010 terjadi jumlah produksi kakao yang tinggi sebesar 66.466 ton dan jumlah produksi terendah terjadi pada tahun 2007 dengan jumlah produksi sebanyak 60.202 ton. Diharapkan kakao Sumatera Utara terus mengalami peningkatan produksi yang juga akan meningkatkan pendapatan (devisa) bagi Sumatera Utara.

Luas lahan merupakan sesuatu yang sangat penting dalam proses produksi ataupun dalam usaha pertanian. Lahan pertanian merupakan penentu dari pengaruh komoditas pertanian. Semakin luas, lahan yang ditanami maka semakin besar jumlah produksi yang dihasilkan oleh lahan tersebut. Irmayani Noer dan Agus (2007) menyatakan " luas lahan pertanian dan produksi per hektar dipengaruhi oleh perubahan harga dan produksi per hektar juga dipengaruhi oleh perubahan luas areal tanam”. Dalam penelitiannya, Irmayani Noer dan Agus (2007) menyimpulkan bahwa "peningkatan produksi sebagai akibat peningkatan jumlah areal tanam”. Dalam pertanian kakao, luas lahan pertanian kakao yang sempit sudah pasti kurang memberikan hasil dibanding lahan yang lebih luas. Semakin sempit luas lahan, semakin rendah pendapatan yang diperoleh, begitupun dengan jumlah produksi kakao yang dihasilkan lahan tersebut pasti lebih sedikit. Berdasarkan laporan Departemen Perindustrian tahun 2012, Sumatera Utara menduduki peringkat ke empat daerah penghasil biji kakao terbesar di Indonesia setelah Sulawesi Selatan, Sulawesi Tengah, dan Sulawesi Tenggara dengan menyumbang sekitar 7,85\% dari seluruh produksi kakao nasional. Menurut data di atas, dapat dikatakan Sumatera Utara bisa menjadi lumbung biji kakao Indonesia. Hanya saja akhir - akhir ini beberapa petani kakao mengubah lahan pertanian kakaonya menjadi lahan sawit karena serangan hama banyak menyerang tanaman kakao. Mudahnya proses penanaman serta pemeliharaan kelapa sawit membuat beberapa petani kakao mengubah haluan menjadi petani sawit.

Berikut tabel yang menunjukkan ekspor kakao Sumatera Utara dalam beberapa tahun : 
Tabel 3. Volume Ekspor Kakao Sumatera Utara

\begin{tabular}{|c|c|}
\hline Tahun & Berat Bersih $(\mathrm{kg})$ \\
\hline 2007 & 46.594 .479 \\
\hline 2008 & 47.820 .752 \\
\hline 2009 & 51.515 .968 \\
\hline 2010 & 58.051 .000 \\
\hline 2011 & 59.198 .005 \\
\hline 2012 & 63.006 .788 \\
\hline 2013 & 57.852 .847 \\
\hline
\end{tabular}

\section{Sumber : BPS Sumatera Utara}

Pada tabel 3. terlihat volume ekspor kakao Sumatera Utara mengalami peningkatan dari tahun 2007-2012 dan pada tahun 2012 ekspor kakao Sumatera mencapai puncaknya, jika dibandingkan dengan tahun - tahun sebelumnya. Kakao yang dimaksudkan data di atas adalah biji kakao dan produk olahannya. Produk olahan biji kakao yang diekspor oleh Sumatera Utara ke beberapa negara adalah bubuk kakao, pasta kakao, mentega kakao, lemak kakao, minyak kakao dan produk coklat dalam bentuk batangan maupun tablet.

Kenaikan produksi kakao Sumatera Utara tentu saja dipicu oleh meluasnya lahan pertanian kakao rakyat di provinsi ini. Untuk memiliki kebun kakao, tidak membutuhkan areal yang luas seperti halnya kebun sawit. Hal inilah yang menyebabkan banyak petani - petani kecil menanam kebunnya yang tidak begitu luas dengan tanaman kakao.

Berikut ini adalah tabel yang menunjukkan luas lahan kakao rakyat di provinsi Sumatera Utara :

Tabel 4. Luas lahan kakao perkebunan rakyat Sumatera Utara

\begin{tabular}{|c|c|c|c|c|}
\hline Tahun & $\begin{array}{c}\text { Belum Produktif } \\
(\text { ha })\end{array}$ & Produktif (ha) & $\begin{array}{c}\text { Tidak Produktif } \\
\text { (ha) }\end{array}$ & Total (ha) \\
\hline 2007 & $15.786,30$ & $38.098,73$ & $2.543,45$ & $56.428,48$ \\
\hline 2008 & $18.906,73$ & $39.667,74$ & $1.646,75$ & $60.221,22$ \\
\hline 2009 & $19.744,94$ & $42.618,26$ & $3.727,75$ & $66.090,95$ \\
\hline 2010 & $16.976,53$ & $39.822,77$ & $2.571,60$ & $59.370,90$ \\
\hline 2011 & $15.365,33$ & $41.465,48$ & $2.451,56$ & $59.282,37$ \\
\hline 2012 & $14.745,67$ & $44.023,56$ & $1.356,65$ & $60.125,88$ \\
\hline 2013 & $14.985,26$ & $41.451,46$ & $1.963,64$ & $58.400,36$ \\
\hline
\end{tabular}

\section{Sumber : Dinas Perkebunan Provinsi Sumatera Utara}

Data di atas menunjukkan bahwa setiap tahunnya luas lahan kakao rakyat di Sumatera Utara semakin meningkat dan puncaknya pada tahun 2009. Hal ini mengindikasikan sampai tahun 2009 semakin banyak petani di Sumatera
Utara yang menanami lahannya dengan tanaman kakao. Namun pada tahun 2010 lahan kakao berkurang jika dibandingkan dengan tahun 2009. Hal ini disebabkan banyaknya petani kakao yang mengalihkan perkebunan 
kakaonya menjadi perkebunan kelapa sawit.

Sumatera Utara mengekspor kakaonya ke beberapa negara, antara lain China, Thailand, Singapura, Filiphina, Malaysia, Amerika Serikat, Spanyol dan negara lainnya. Tahun 2009 tujuan ekspor terbesar biji kakao terbesar Sumatera Utara adalah negara Malaysia disusul oleh Amerika Serikat dan Singapura. Setiap tahunnya Amerika Serikat masih menjadi tujuan utama ekspor kakao Sumatera Utara. Sebagai pengonsumsi kakao terbesar di dunia, sudah sepantasnya Amerika tetap menjadi salah satu tujuan utama ekspor kakao Sumatera Utara.

Berdasarkan data tentang areal perkebunan kakao rakyat di Sumatera Utara yang meningkat setiap tahunnya dan data yang menunjukkan bahwa Amerika Serikat adalah negara pengimpor biji kakao terbanyak di dunia, maka ekspor kakao Sumatera Utara ke Amerika Serikat merupakan hal yang sangat penting untuk diperhatikan dan diperhitungkan. Selain dari luas lahan, faktor yang mempengaruhi jumlah produksi adalah jumlah permintaan. Sadono Sukirno (2010) menjelaskan bahwa "isu pokok yang dianalisis dalam teori mikroekonomi adalah : bagaimana caranya menggunakan faktor-faktor produksi yang tersedia secara efisien agar kemakmuran masyarakat dapat dimaksimumkan".

Analisis seperti ini dibuat berdasarkan kepada pemikiran bahwa kebutuhan dan keinginan manusia tidak terbatas sedangkan kemampuan faktor-faktor produksi menghasilkan barang dan jasa untuk memenuhi kebutuhan dan keinginan masyarakat adalah terbatas. Berdasarkan kepada kedua pemikiran ini, teori mikroekonomi bertitik tolak kepada asumsi bahwa faktor-faktor produksi yang tersedia selalu sepenuhnya digunakan. Keadaan ini mendorong masyarakat untuk memikirkan cara yang paling efisien dalam menggunakan faktor-faktor produksi yang tersedia. Pemanfaatan tanaman kakao di Indonesia mengalami peningkatan dari sisi keragaman produk dan kegunaan. "Salah satunya adalah penelitian yang dilakukan oleh Dian Anggraeni Elisabeth tentang pembuatan nata de kakao yang baik untuk kesehatan "(Tabloid Sinar Tani, 2006). Selain itu upaya diversivikasi dari tanaman kakao ini tidak hanya untuk produk makanan dan minuman yang sudah umum dikenal oleh masyarakat, namun dalam perkembangannya dapat dimanfaatkan untuk kecantikan (masker kakao), sabun mandi dari sari kakao dan limbah dari tanaman yang berupa daun dan kulit buah kakao dapat dimanfaatkan untuk makanan ternak sebagaimana hasil penemuan pusat Penelitian Kopi dan Kakao (PPKK) Jember.

\section{METODE PENELITIAN \\ Lokasi Penelitian}

Lokasi penelitian dilakukan di

Badan Pusat Statistik Provinsi Sumatera Utara yang beralamat di Jl.Asrama No.179 Medan.

\section{Sumber Data}

Yang menjadi sumber data dalam penelitian ini adalah data sekunder yang berasal dari Badan Pusat Statistik Provinsi Sumatera Utara yang terdiri dari: 
1. Data luas lahan kakao Sumatera Utara dari tahun 2007-2012

2. Data permintaan kakao Sumatera Utara dari tahun 2007-2012

3. Data produksi kakao Sumatera Utara dari tahun 2007-2012

\section{Variabel Penelitian dan Defenisi Operasional \\ Variabel Penelitian}

Adapun yang menjadi variabel penelitian ini adalah :

a. Variabel terikat (Y) adalah Produksi Kakao

b. Variabel bebas (X) adalah

$\mathrm{X}_{1}$ : Luas Lahan

$\mathrm{X}_{2}$ : Permintaan

\section{Defenisi Operasional}

Luas lahan $\left(\mathrm{X}_{1}\right)$ adalah areal/tempat yang digunakan untuk melakukan usahatani diatas sebidang tanah, yang diukur dalam satuan hektar (ha).

Permintaan $\left(\mathrm{X}_{2}\right)$ adalah jumlah kebutuhan konsumen yang diukur dalam satuan ton.

Produksi (Y) adalah banyaknya hasil yang dihasilkan oleh produsen yang ditawarkan kepada konsumen yang diukur dalam satuan ton.

\section{Uji Regresi Linier Berganda}

Untuk mengetahui seberapa besar pengaruh yang ditimbulkan dari variabel luas lahan $\left(\mathrm{X}_{1}\right)$ dan variabel permintaan $\left(\mathrm{X}_{2}\right)$ terhadap produksi (Y) maka digunakan teknik analis data dengan rumus regresi linier berganda sebagai berikut :

$Y=a+b_{1} X_{1}+b_{2} X_{2}+e$
Dimana :

Y : Produksi Kakao

a : Konstanta

$\mathrm{b}_{1} \quad$ : Koefisien arah regresi Luas Lahan

$\mathrm{b}_{2} \quad$ : Koefisien arah regresi Jumlah

Permintaan

$\mathrm{X}_{1}$ : Luas Lahan

$\mathrm{X}_{2}$ : Permintaan

E : Koefisien Lain

\section{Uji Hipotesis}

Uji F (Simultan)

Uji F yaitu suatu uji untuk mengetahui pengaruh variabel bebas, yaitu Promosi Jabatan (X1), Insentif (X2), secara simultan berpengaruh terhadap variabel terikat, yaitu Kinerja (Y). Kriteria yang digunakan adalah :

1. $\mathrm{H} 0: \mathrm{b} 1=\mathrm{b} 2=0$, artinya tidak ada pengaruh yang signifikan dari variabel bebas, yaitu Luas Lahan (X1), Permintaan (X2), secara simultan terhadap variabel terikat, yaitu Produksi (Y).

2. На : $\mathrm{b} 1 \neq \mathrm{b} 2 \neq 0$, artinya ada pengaruh positif yang signifikan dari variabel bebas, yaitu yaitu Luas Lahan (X1), Permintaan (X2), secara simultan terhadap variabel terikat, yaitu Produksi (Y).

Kriteria Pengambilan Keputusan :

Ho diterima jika $\mathrm{F}_{\text {hitung }}<\mathrm{F}_{\text {tabel }}$, pada $\alpha=5 \%$

Ha diterima jika $\mathrm{F}_{\text {hitung }}>\mathrm{F}_{\text {tabel, }}$ pada $\alpha=5 \%$

Adapun rumus yang digunakan untuk mengetahui tingkat signifikansi variable $\mathrm{X} 1$ dan $\mathrm{X} 2$ secara bersama-sama terhadap variable $\mathrm{Y}$ digunakan rumus uji $\mathrm{F}$ regresi (Sugiyono 2005 : 190) yaitu :

$$
\mathrm{Fh}=\frac{\mathrm{R}^{2} / \mathrm{k}}{\left(1-\mathrm{R}^{2}\right) /(\mathrm{n}-\mathrm{k}-}
$$




\section{Uji t (Parsial)}

Uji parsial atau koefesien regresi dimaksud untuk memastikan apakah variable bebas yang terdapat dalam persamaan tersebut secara individu berpengaruh secara signifikan terhadap nilai variable terikat. Caranya dengan melakukan pengujian terhadap koefisien regresi setiap variable bebas dengan menggunakan uji t. Langkah langkah pengujian untuk uji $\mathrm{t}$ adalah sebagai berikut :

1. Menentukan model hipotesis untuk Ho dan $\mathrm{Ha}$

2. Ho : $\mathrm{b} 1=0$, artinya secara parsial tidak terdapat pengaruh yang positif dan signifikan dari variable bebas (X) terhadap variable terikat $(\mathrm{Y})$. Sedangkan jika Ha : b1 $\neq 0$, artinya secara parsial terdapat pengaruh yang positif dan signifikan dari variable terikat $(\mathrm{Y})$

3. Mencari nilai $t$ tabel dengan cara menentukan tingkat kesalahan dan derajat kebebasan. Tingkat kesalahan nyang dipakai adalah 5\% dan derajat kebebasan $(\mathrm{df})=\mathrm{n}-\mathrm{k}$, dimana $n$ adalah jumlah sampel dan $\mathrm{k}$ adalah jumlah variable independen yang digunakan.
4. Menetukan kriteria pengambilan keputusan Ho diterima jika $\mathrm{t}$ hitung $<\mathrm{t}$ tabel pada $\alpha=5 \%$

Ha diterima jika $\mathrm{t}$ hitung $>\mathrm{t}$ tabel pada $\alpha=5 \%$

Adapun rumus yang digunakan untuk menguji masing masing hipotesis ini adalah dengan uji t parsial (Ridwan $2007: 125$ ) yaitu:

$$
\mathrm{t}_{\text {terhitung }}=\frac{\sqrt[r]{n-2}}{\sqrt{n-r^{2}}}
$$

\section{Koefisien Determinasi $\left(\mathbf{R}^{2}\right)$}

Uji ini dilakukan untuk mengukur seberapa besar pengaruh yang diberikan variabel bebas terhadap variabel terikat. Jika $\mathrm{R}^{2}$ semakin medekati satu maka pengaruh variabel bebas terhadap variabel terikat mempunyai pengaruh yang besar dan sebaliknya apabila $\mathrm{R}^{2}$ mendekati nol maka pengaruh variabel bebas terhadap variabel terikat mempunyai pengaruh yang kecil.

\section{HASIL DAN PEMBAHASAN \\ PENELITIAN \\ Hasil Penelitian \\ Analisis Regresi Berganda}

Persamaan regresi berganda secara umum adalah :

$$
\mathbf{Y}=\mathbf{a}+\mathbf{b}_{1} \mathbf{X}_{1}+\mathbf{b}_{2} \mathbf{X}_{2}+\mathbf{e}
$$

Tabel 5. Hasil Uji Regresi Linier Berganda

\begin{tabular}{|c|c|c|c|c|c|c|}
\hline \multirow{2}{*}{\multicolumn{2}{|c|}{ Model }} & \multicolumn{2}{|c|}{ Unstandardized Coefficients } & \multirow{2}{*}{$\begin{array}{c}\text { Standardized } \\
\text { Coefficients }\end{array}$} & \multirow[b]{2}{*}{$\mathrm{t}$} & \multirow[b]{2}{*}{ Sig. } \\
\hline & & B & Std. Error & & & \\
\hline \multirow[t]{3}{*}{1} & (Constant) & -4397.631 & 21908.322 & & -.201 & .854 \\
\hline & LuasLahan & .820 & .288 & .921 & 2.847 & .015 \\
\hline & Permintaan & -.046 & .147 & -.101 & -.311 & .776 \\
\hline
\end{tabular}

Coefficients $^{\mathrm{a}}$

a. Dependent Variable: Produksi 


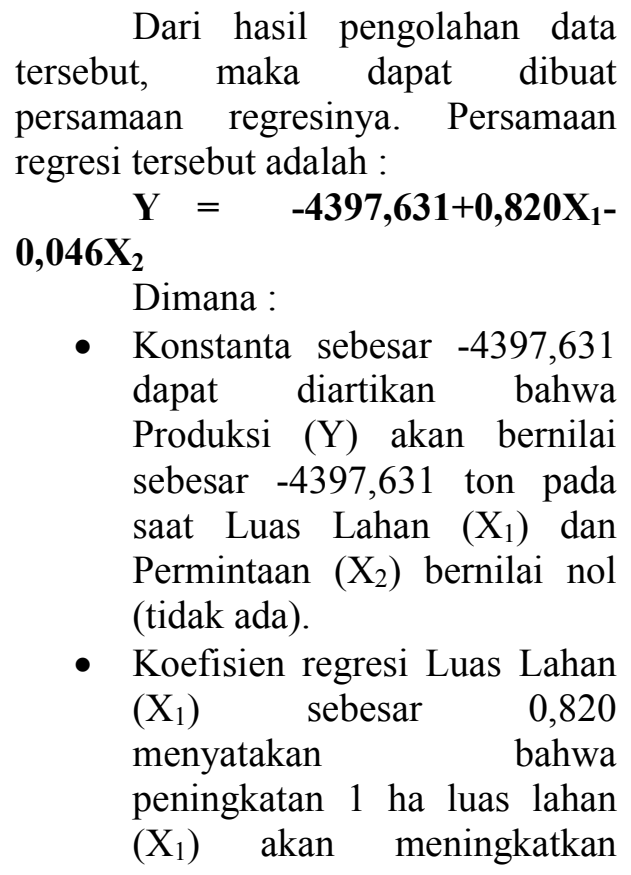

Dari hasil pengolahan data tersebut, maka dapat dibuat persamaan regresinya. Persamaan regresi tersebut adalah :

\section{$0,046 X_{2}$ \\ Dimana :}

$Y=-4397,631+0,820 X_{1}-$

- Konstanta sebesar -4397,631 dapat diartikan bahwa Produksi (Y) akan bernilai sebesar $-4397,631$ ton pada saat Luas Lahan $\left(\mathrm{X}_{1}\right)$ dan Permintaan $\left(\mathrm{X}_{2}\right)$ bernilai nol (tidak ada).

- Koefisien regresi Luas Lahan $\left(\mathrm{X}_{1}\right) \quad$ sebesar $\quad 0,820$ menyatakan bahwa peningkatan 1 ha luas lahan $\left(\mathrm{X}_{1}\right)$ akan meningkatkan

\author{
Produksi (Y) sebesar 0,820 \\ ton.
}

- Koefisien regresi Permintaan $\left(\mathrm{X}_{2}\right) \quad$ sebesar $\quad-0,046$ menyatakan bahwa kenaikan 1 ton permintaan $\left(\mathrm{X}_{2}\right)$ akan mengurangi Produksi (Y) sebesar 0,046 ton.

\section{Pengujian Hipotesis \\ Pengujian Hipotesis Secara Simultan menggunakan Uji-F}

Uji hipotesis secara simultan diperlukan untuk mengetahui apakah model regresi sudah benar atau tidak. Uji hipotesis menggunakan angka $\mathrm{F}$, yang diperoleh dari tabel Anova berikut ini :

Tabel 6. Hasil Uji F

ANOVA $^{\mathrm{D}}$

\begin{tabular}{|ll|r|r|r|r|r|}
\hline Model & & Sum of Squares & Df & Mean Square & \multicolumn{1}{c|}{ F } & Sig. \\
\hline 1 & Regression & $6.312 \mathrm{E} 7$ & 2 & $3.156 \mathrm{E} 7$ & $\mathbf{1 0 . 8 9 5}$ & $\mathbf{. 0 2 6 ^ { \mathbf { a } }}$ \\
& Residual & $1.934 \mathrm{E} 7$ & 3 & 6448130.495 & & \\
& & & & & \\
& Total & $8.247 \mathrm{E} 7$ & 5 & & & \\
\hline
\end{tabular}

a. Predictors: (Constant), Permintaan, LuasLahan

b. Dependent Variable: Produksi

Pengujian hipotesis dilakukan

dengan cara membandingkan

besarnya angka $\mathrm{F}_{\text {hitung }}$ dengan $\mathrm{F}_{\text {tabel, }}$, dengan kriteria sebagai berikut :

Jika $F_{\text {hitung }}>F_{\text {tabel, }}$, maka Ho ditolak dan Ha diterima

Jika $F_{\text {hitung }}>F_{\text {tabel }}$, maka Ho diterima dan Ha ditolak

Dimana hipotesis yang digunakan dalam uji secara simultan dalam penelitian ini yaitu :

$\mathrm{Ha}=$ Terdapat pengaruh yang signifikan secara simultan antara Luas Lahan $\left(\mathrm{X}_{1}\right)$ dan Permintaan $\left(\mathrm{X}_{2}\right)$ terhadap Produksi (Y)

Ho = Tidak terdapat pengaruh yang signifikan secara simultan antara

Luas Lahan $\left(\mathrm{X}_{1}\right)$ dan Permintaan $\left(\mathrm{X}_{2}\right)$ terhadap Produksi (Y)

Berdasarkan tabel 6., angka $F_{\text {hitung }}$ yang diperoleh dari hasil perhitungan adalah sebesar 10,895. Sedangkan $F_{\text {tabel }}$ dihitung dengan ketentuan yaitu taraf signifikansi $95 \%$ dan alpha $5 \%$ serta derajat kebebasan (dk) dengan ketentuan n-2 =6-2 $=4$. Dengan ketentuan tersebut diperoleh angka $\mathrm{F}_{\text {tabel }} \rightarrow 9,55$. Karena $\mathrm{F}_{\text {hitung }}>$ $\mathrm{F}_{\text {tabel }}$ yang berarti bahwa Ho ditolak dan Ha diterima, sehingga dapat disimpulkan bahwa terdapat pengaruh yang signifikan dan simultan antara Luas Lahan $\left(\mathrm{X}_{1}\right)$ dan Permintaan $\left(\mathrm{X}_{2}\right)$ terhadap Produksi (Y). 


\section{Pengujian Hipotesis Secara Parsial menggunakan Uji-t}

Untuk melihat besarnya pengaruh antara Luas Lahan $\left(\mathrm{X}_{1}\right)$ dan Permintaan $\left(\mathrm{X}_{2}\right)$ terhadap Produksi
(Y) secara parsial, digunakan Uji $\mathrm{t}$ dengan menggunakan program SPSS, maka di dapat hasil uji $t$, yang hasilnya disajikan pada tabel berikut ini.

Tabel 7. Hasil Uji t

Coefficients $^{a}$

\begin{tabular}{|c|c|c|c|c|c|c|}
\hline \multirow{2}{*}{\multicolumn{2}{|c|}{ Model }} & \multicolumn{2}{|c|}{ Unstandardized Coefficients } & \multirow{2}{*}{$\begin{array}{c}\text { Standardized } \\
\text { Coefficients }\end{array}$} & \multirow[b]{2}{*}{$\mathrm{t}$} & \multirow[b]{2}{*}{ Sig. } \\
\hline & & B & Std. Error & & & \\
\hline \multirow[t]{3}{*}{1} & (Constant) & -4397.631 & 21908.322 & & -.201 & .854 \\
\hline & LuasLahan & .820 & .288 & .921 & 2.847 & .015 \\
\hline & Permintaan & -.046 & .147 & -.101 & -.311 & .776 \\
\hline
\end{tabular}

a. Dependent Variable: Produksi

\section{Pengujian Pengaruh Luas Lahan $\left(\mathrm{X}_{1}\right)$ terhadap Produksi (Y)}

Secara individual uji statistik yang digunakan adalah uji t. Hasil perhitungan SPSS diperoleh angka $t_{\text {hitung sebesar 2.874. Untuk }}$ memperoleh besarnya $t_{\text {tabel }}$ dilakukan perhitungan dimana taraf signifikansi $95 \%$ dan alpha 5\%, serta derajat kebebasan (dk) dengan ketentuan $\mathrm{dk}$ $=\mathrm{n}-2$ atau $6-2=4$. Dari ketentuan tersebut diperoleh angka $t$ tabel sebesar $\rightarrow 2,776$.

Hipotesis yang digunakan dalam uji secara parsial dalam penelitian ini yaitu :

$\mathrm{Ha}_{1}=$ Terdapat pengaruh yang signifikan dari Luas Lahan $\left(\mathrm{X}_{1}\right)$ terhadap Produksi (Y).

$\mathrm{Ho}_{1}=$ Tidak terdapat pengaruh yang signifikan dari Luas Lahan $\left(\mathrm{X}_{1}\right)$ terhadap Produksi (Y).

Pengujian hipotesis dilakukan dengan cara membandingkan besarnya angka $t_{\text {hitung }}$ dengan $t_{\text {tabel }}$ dengan kriteria sebagai berikut :

Jika $t_{\text {hitung }}>t_{\text {tabel}}$, maka $\mathrm{Ho}_{1}$ ditolak dan $\mathrm{Ha}_{1}$ diterima

Jika $t_{\text {hitung }}<t_{\text {tabel }}$, maka $\mathrm{Ho}_{1}$ diterima dan $\mathrm{Ha}_{1}$ ditolak
Berdasarkan tabel 7. diatas, diperoleh hasil 2,874>2,776, maka $\mathrm{Ho}_{1}$ ditolak dan $\mathrm{Ha}_{1}$ diterima. Artinya, terdapat pengaruh yang signifikan dari Luas Lahan $\left(\mathrm{X}_{1}\right)$ terhadap Produksi (Y)

Besarnya pengaruh luas lahan terhadap produksi dapat dilihat pada tabel 4.6 dimana besarnya pengaruh luas lahan terhadap produksi sebesar 0,871 atau $87,1 \%$ sehingga dapat disimpulkan bahwa secara parsial luas lahan berpengaruh signifikan terhadap produksi.

\section{Pengujian pengaruh Permintaan $\left(\mathrm{X}_{2}\right)$ terhadap Produksi (Y)}

Hasil perhitungan SPSS diperoleh angka $t_{\text {hitung }}$ sebesar $-0,311$. Untuk memperoleh besarnya $t_{\text {tabel }}$ dilakukan perhitungan dimana taraf signifikansi 95\% dan alpha 5\% serta derajat kebebasan (dk) dengan ketentuan $\mathrm{dk}=\mathrm{n}-2$ atau $6-2=4$. Dari ketentuan tersebut diperoleh angka $t$ tabel sebesar $\rightarrow 2,776$.

Dimana hipotesis yang digunakan dalam uji secara parsial dalam penelitian ini yaitu : 
$\mathrm{Ho}_{2}=$ Terdapat pengaruh yang signifikan dari Permintaan $\left(\mathrm{X}_{2}\right)$ terhadap Produksi (Y).

$\mathrm{Ha}_{1}=$ Tidak terdapat pengaruh yang signifikan dari Permintaan $\left(\mathrm{X}_{2}\right)$ terhadap Produksi (Y).

Pengujian hipotesis dilakukan dengan cara membandingkan besarnya angka $t_{\text {hitung dengan }} t_{\text {tabel }}$ dengan kriteria sebagai berikut :

Jika $t_{\text {hitung }}>t_{\text {tabel}}$, maka $\mathrm{Ho}_{1}$ ditolak dan $\mathrm{Ha}_{1}$ diterima

Jika $t_{\text {hitung }}<t_{\text {tabel }}$, maka $\mathrm{Ho}_{1}$ diterima dan $\mathrm{Ha}_{1}$ ditolak

Berdasarkan tabel 4.10 diatas, diperoleh hasil $-0,311<2,776$, maka $\mathrm{Ho}_{1}$ diterima dan $\mathrm{Ha}_{1}$ ditolak. Artinya, tidak terdapat pengaruh yang signifikan dari Permintaan $\left(\mathrm{X}_{2}\right)$ terhadap Produksi (Y). Dari hasil penelitian dimana dilihat pada tabel 4.6 besarnya pengaruh permintaan hanya 0,004 atau sebesar $0,4 \%$ sehingga dianggap tidak berpengaruh signifikan terhadap produksi.

\section{Koefisien Determinasi (R Square)}

Determinan digunakan untuk mengetahui seberapa besar variabel independen mampu menjelaskan pengaruh variabel dependen. Besarnya koefisien determinasi dapat dilihat pada $r$ square dan dinyatakan dalam presentase. Hasil koefisien determinasi dapat dilihat pada tabel berikut ini.

\section{Tabel 8. Hasil Uji Koefisien Determinasi}

Model Summary ${ }^{\mathrm{D}}$

\begin{tabular}{|l|r|r|r|r|r|}
\hline Model & \multicolumn{1}{|c|}{$\mathrm{R}$} & R Square & Adjusted R Square & $\begin{array}{c}\text { Std. Error of the } \\
\text { Estimate }\end{array}$ & Durbin-Watson \\
\hline 1 & $.875^{\mathrm{a}}$ & .765 & .609 & 2539.31693 & 1.466 \\
\hline
\end{tabular}

a. Predictors: (Constant), Permintaan, LuasLahan

b. Dependent Variable: Produksi

Dari tabel tersebut dapat diketahui besarnya angka $\mathrm{R}^{2}$ adalah 0,765 yang berarti variabel Luas Lahan $\left(\mathrm{X}_{1}\right)$ dan Permintaan $\left(\mathrm{X}_{2}\right)$ menjelaskan pengaruh terhadap variabel Produksi (Y) sebesar 76,5\% $\left(\mathrm{R}^{2} \times 100 \% ; 0,765 \times 100 \%=76,5 \%\right)$ sedangkan sisanya $23,5 \%\left(100 \%-\mathrm{R}^{2}\right)$ dijelaskan oleh variabel-variabel lain di luar model penelitian ini.

\section{Pembahasan Hasil Penelitian}

Berdasarkan hasil penelitian yang dilakukan terhadap data tahunan yaitu data luas lahan, permintaan dan produksi dari tahun 2007-2012 diperoleh hasil bahwa terdapat pengaruh yang signifikan dari Luas Lahan $\left(\mathrm{X}_{1}\right)$ terhadap Produksi $(\mathrm{Y})$ sedangkan Permintaan $\left(\mathrm{X}_{2}\right)$ tidak berpengaruh signifikan terhadap Produksi (Y). Dari perhitungan $\mathrm{R}$ square juga diperoleh nilai $\mathrm{R}^{2}=0,765$ yang berarti luas lahan dan permintaan memberikan pengaruh sebesar $\quad 76,5 \%$ sedangkan $\quad 23,5 \%$ dipengaruhi oleh faktor lain seperti harga kakao, stok kakao yang tidak diekspor dari tahun sebelumnya, pajak ekspor, serta kurs valuta asing.

Untuk teori-teori yang berkembang yang menyatakan bahwa luas lahan berpengaruh positif terhadap produksi berdasarkan penelitian yang dilakukan bahwa terbukti jika luas lahan meningkat maka produksi akan meningkat hal ini diperoleh dari pengolahan data yang 
dilakukan bahwa $t_{\text {hitung }}>\mathrm{t}_{\text {tabel }}: 2,874$ $>$ 2,776, maka $\mathrm{Ho}_{1}$ ditolak dan $\mathrm{Ha}_{1}$ diterima. Artinya terdapat pengaruh yang signifikan dari luas lahan $\left(\mathrm{X}_{1}\right)$ terhadap produksi $(\mathrm{Y})$. besarnya pengaruh luas lahan terhadap produksi sebesar 0,871 atau $87,1 \%$ sehingga dapat disimpulkan bahwa secara parsial luas lahan berpengaruh signifikan terhadap produksi. Hal ini sesuai kenyataan di lapangan apabila luas lahan kakao meningkat maka produksi juga akan meningkat.

Berdasarkan teori-teori yang berkembang yang menyatakan bahwa permintaan berpengaruh negatif terhadap produksi ternyata dari penelitian yang dilakukan terbukti bahwa permintaan tidak berpengaruh signifikan terhadap produksi dimana dari pengolahan data yang dilakukan diperoleh hasil $\mathrm{t}_{\text {hitung }}<\mathrm{t}_{\text {tabel }} ;-0,311<$ 2,776, maka $\mathrm{Ho}_{1}$ diterima dan $\mathrm{Ha}_{1}$ ditolak. Artinya, tidak terdapat pengaruh yang signifikan dari Permintaan $\left(\mathrm{X}_{2}\right)$ terhadap Produksi (Y). Dari hasil penelitian dimana dilihat pada tabel 4.6 besarnya pengaruh permintaan hanya 0,004 atau sebesar $0,4 \%$ sehingga dianggap tidak berpengaruh signifikan terhadap produksi. Pada keadaan di lapangan bahwa permintaan tidak berdampak besar pada produksi kakao Sumatera Utara, hal ini disebabkan rendahnya mutu kakao.

Hasil pengujian hipotesis bahwa diperoleh hasil angka $\mathrm{F}_{\text {hitung }}=$ 10,895 sedangkan $\mathrm{F}_{\text {tabel }}=9,55$. Karena $F_{\text {hitung }}>F_{\text {tabel }}$ yang berarti bahwa Ho ditolak dan Ha diterima, sehingga dapat disimpulkan bahwa terdapat pengaruh yang signifikan dan simultan antara Luas Lahan $\left(\mathrm{X}_{1}\right)$ dan Permintaan $\left(\mathrm{X}_{2}\right)$ terhadap Produksi (Y).

\section{PENUTUP}

Berdasarkan hasil analisis dan pembahasan Pengaruh Luas Lahan dan Permintaan terhadap Produksi Kakao di Sumatera Utara yang telah dilakukan, maka penulis menarik beberapa kesimpulan sebagai berikut :

1. Diperoleh persamaan regresi sebagai berikut $Y=-4397,631+0,820 X_{1}-0,046 X_{2}$ Yang berarti :

- Konstanta sebesar -4397,631 dapat diartikan bahwa Produksi (Y) akan bernilai sebesar 4397,631 ton pada saat Luas Lahan $\left(\mathrm{X}_{1}\right)$ dan Permintaan $\left(\mathrm{X}_{2}\right)$ bernilai nol (tidak ada).

- Koefisien regresi Luas Lahan $\left(\mathrm{X}_{1}\right)$ sebesar 0,820 menyatakan bahwa peningkatan 1 ha luas lahan $\left(\mathrm{X}_{1}\right)$ akan meningkatkan Produksi (Y) sebesar 0,820 ton.

- Koefisien regresi Permintaan $\left(\mathrm{X}_{2}\right)$ sebesar -0,046 menyatakan bahwa kenaikan 1 ton permintaan $\left(\mathrm{X}_{2}\right)$ akan mengurangi Produksi (Y) sebesar 0,046 ton.

2. Diperoleh nilai $\mathrm{R}^{2}$ sebesar 0,765 yang berarti luas lahan $\left(\mathrm{X}_{1}\right)$ dan permintaan $\left(\mathrm{X}_{2}\right)$ menjelaskan pengaruh terhadap variabel Produksi (Y) sebesar 76,5\% $\left(\mathrm{R}^{2} \mathrm{x}\right.$ $100 \% ; 0,765 \times 100 \%=76,5 \%)$ sedangkan sisanya $23,5 \%(100 \%$ $\mathrm{R}^{2}$ ) dijelaskan oleh variabelvariabel lain di luar model penelitian ini

3. Setelah dilakukan Uji Hipotesis secara Simultan (Uji - F), bahwa diperoleh variabel luas lahan $\left(\mathrm{X}_{1}\right)$ dan permintaan $\left(\mathrm{X}_{2}\right)$ secara bersama-sama berpengaruh signifikan terhadap produksi $(\mathrm{Y})$ hal ini diperoleh nilai $\mathrm{F}_{\text {hitung }}=$ 10,895 lebih besar dari $\mathrm{F}_{\text {tabel }}=$ 9,55 . 
4. Setelah dilakukan Uji Hipotesis secara parsial (Uji - t) maka dapat disimpulkan bahwa :

a. Variabel luas lahan $\left(\mathrm{X}_{1}\right)$ berpengaruh secara signifikan terhadap produksi (Y) hal ini diperoleh hasil $t_{\text {hitung }}>t_{\text {tabel }}$ ; 2,874>2,776

b. Variabel permintaan $\left(\mathrm{X}_{2}\right)$ tidak berpengaruh secara signifikan terhadap produksi $(\mathrm{Y})$ dimana nilai $\mathrm{t}_{\text {hitung }}<\mathrm{t}_{\text {tabel }} ;-0,311<$ 2,776 .

DAFTAR PUSTAKA

Abidin, Zainal. 2008. Analisis Ekspor Kakao Indonesia. Jurnal Aplikasi Manajemen, Volume 6, Nomor 1, April 2008, Pascasarjana UPN "Veteran" Jatim Surabaya.

Ahyari, Agus. 2002. Manajemen Produksi : Pengendalian Produksi. Edisi 4. Buku 2. Yogyakarta : BPFEYogyakarta.

Arleen. 2006. Analisis Faktor-Faktor Yang Mempengaruhi Ekspor Kakao Indonesia. Skripsi. Program Studi Manajemen Agribisnis. Fakultas Pertanian, IPB.

Assauri, Sofyan. 2007. Manajemen Pemasaran, Dasar, konsep, dan Strategi. Edisi Ketujuh. Jakarta : Rajawali.

Basu Swastha dan Ibnu Sukotjo. 2002. Pengantar Bisnis Modern. Edisi Keenam. Yogyakarta: Liberty.

Daniel, M. 2004. Pengantar Ekonomi Pertanian. Jakarta : Bumi Aksara.
Edilius, dkk. Pengantar Ekonomi Perusahaan.Jakarta : PT Rineka Cipta.

Farida, Milias. 2009. Analisis Permintaan Ekspor Biji Kakao Sulawesi Tengah Oleh Malaysia. Tesis. Program Studi Magister Ilmu Ekonomi dan Studi Pembangunan. Universitas Diponegoro.

Ghozali, Imam. 2005. Aplikasi Multivrate Dengan Program SPSS. Semarang : Badan Penerbit Universitas Diponegoro.

Hadipurnomo. 2000. Dampak Kebijakan Produksi dan Perdagangan Terhadap Permintaan dan Penawaran Kakao di Indonesia. Tesis. Institut Pertanian Bogor.

Handoko, T. Hani. 2003. Manajemen. Cetakan Kedelapanbelas. Yogyakarta : BPFEYogyakarta.

Hasizah, Mochtar. 2011. Prospek Industri Pengolahan Kakao Di Makassar. Jurnal Agrisistem, Volume 7, Nomor 1. Makassar.

Junaidi. 2001. Analisis Penawaran Dan Permintaan Kakao di Pasar Internasional : Suatu Analisis Simulasi. Tesis. Program Pasca Sarjana. Fakultas Pertanian. Institut Pertanian Bogor.

Komalasari, Irma.2009. Analisis Faktor-Faktor Yang Mempengaruhi Penawaran Ekspor Biji Kakao Indonesia. Skripsi. Program Studi Manajemen Agribisnis. Fakultas Pertanian. IPB. 
Mubyarto. 2007. Pengantar Ekonomi Pertanian. Jakarta : LP3ES.

Muhammad, Arsyad. 2011. Analisis Dampak Kebijakan Pajak Ekspor Dan Subsidi Harga Pupuk Terhadap Produksi Dan Ekspor Kakao Indonesia Pasca Putaran Uruguay. Jurnal Sosial Ekonomi, Volume 8, Nomor 1. Balikpapan.

Nazaruddin. 2002. Komoditi Ekspor Pertanian. Edisi Keempat. Jakarta : Swadaya.

Riduwan. 2007. Rumus dan Data Dalam Analisis Statistika. Bandung : Alfabeta.

Rita, Mariati. 2009. Pengaruh Produksi Nasional,

Konsumsi Dunia Dan Harga Dunia Terhadap Ekspor Crude Palm Oil (CPO) Di Indonesia. Jurnal EPP, Volume 6, Nomor 1, 2009.

Salomo Julius. 2012. Pengaruh Pajak Ekspor Dan Jumlah Produksi Terhadap Volume Ekspor Kakao Di Sumatera Utara. Skripsi. Jurusan Manajemen. Fakultas Ekonomi. Unimed.

Salvatore. 2004. Ekonomi Internasional. Edisi Kelima. Penerbit : Erlangga.

Setiawan, A. I. 2003. Penghijauan Lahan Kritis. Jakarta : Swadaya.

Siallagan, Wahyu. 2010. Analisis Faktor-Faktor Yang Mempengaruhi Ekspor Karet Di Sumatera Utara. Skripsi. Jurusan Manajemen. Fakultas Ekonomi. Unimed.

Soeharno.2007. Metode Penelitian Bisnis. Jakarta : Andi.
Soegyono. 2006. Metode Penelitian Bisnis. Jakarta. Penerbit : Tarsito.

Sukirno,Sadono. 2010. Pengantar Teori Ekonomi. Jakarta : Raja Grafindo Persada.

Suryawati. 2007. Teori Ekonomi Produksi. Jakarta : Raja Grafindo Persada.

Syaid, E. Gumbira. 2006. Review Kajian, Penelitian dan Pengembangan Agroindustri Strategi Nasional, Kelapa Sawit, Kakao dan Karet. Jurnal Rantai Inti Kelapa Sawit, Volume 19, Nomor 1, Tahun 2006, Bogor.

https://www.bps.go.id

http://ms.wikipedia.org/wiki 